Jurnal Mahasiswa BK An-Nur : Berbeda, Bermakna, Mulia

Volume 7 Nomor 2 Tahun 2021

Tersedia Online: https://ojs.uniska-bjm.ac.id/index.php/AN-NUR

p-ISSN. 2460-9722 | e-ISSN. 2622-8297

\title{
KORELASI DUKUNGAN ORANG TUA TERHADAP KEPUASAN PEMILIHAN JURUSAN SISWA KELAS SMK NEGERI 1 SIMPANG EMPAT KABUPATEN BANJAR
}

\author{
Melly ${ }^{1}$, Sultani², Aminah ${ }^{3}$. \\ Universitas Islam Kalimantan Muhammad Arsyad Al-Banjari Banjarmasin \\ mellyaza17@gmailcom/087817191065
}

\begin{abstract}
ABSTRAK
Abstrak : Dukungan orang tua merupakan bantuan yang diberikan orang tua sebagaimana orang yang bertanggung jawab terhadap pendidikan ataupun keperluan hidup lainnya. Dalam memutuskan pemilihan jurusan, orangtua juga memiliki peran untuk terlibat dalam proses pengambilan keputusan jurusan pendidikan pada anaknya. Adapun tujuan penelitian yang akan dilaksanakan adalah untuk mengetahui korelasi antara dukungan orang tua terhadap kepuasan pemilihan jurusan siswa kelas XI di SMK Negeri 1 Simpang Empat Kabupaten Banjar. Desain penelitian ini adalah penelitian korelasi, suatu penelitian yang melibatkan tindakan pengumpulan data, guna menentukan apakah ada hubungan dan tingkat hubungan antara dua variabel atau lebih. Teknik Pengumpulan data yang diperlukan dalam penelitian diambil dengan menggunakan angket (kuesioner) berbentuk checklist. Adapun hasil penelitian uji korelasi dengan rumus korelasi spearman rank, pada penelitian ini yakni terdapat hubungan antara variabel dukungan orangtua dengan variabel kepuasan memilih jurusan pada siswa SMK menunjukan nilai korelasi yaitu 0,660 (>) 0,05 maka dua variabel tersebut termasuk memiliki hubungan berkorelasi. Diharapkan guru dan konselor dapat memberikan pengarahan atau sosialisasi mengenai pentingnya program jurusan yang ada di sekolah, sehingga siswa tidak kekurangan informasi, bagi orang tua, agar orang tua saling memberikan dukungan penuh pada anak, baik berupa dukungan instrument, informasi, penghargaan, dan emosi, hal ini penting mengingat kondisi/suasana yang sedang terjadi mempengaruhi pemilihan jurusan.
\end{abstract}

Kata Kunci : Dukungan Orang Tua, Kepuasan, Pemilihan Jurusan

\begin{abstract}
Abstract : Parental support is assistance provided by parents as people who are responsible for education or other life necessities. In deciding the choice of a major, parents also have a role to be involved in the decisionmaking process of the education department for their children. The research objective that will be carried out is to determine the correlation between parental support and satisfaction in the selection of class XI students at SMK Negeri 1 Simpang Empat, Banjar Regency. The design of this research is correlational research, a study that involves the act of collecting data, in order to determine whether there is a relationship and the level of relationship between two or more variables. Data collection techniques needed in the study were taken using a questionnaire in the form of a checklist. The research results of the correlation test with the formula correlation spearman rank, in this study there is a relationship between the parental support variable and the satisfaction variable of choosing a major in vocational students, which shows a correlation value of 0.660 (>) 0.05 , so the two variables are correlated. It is hoped that teachers and counselors can provide direction or socialization regarding the importance of majoring programs in schools, so that students do not lack information, for parents, so that parents give full support to each other, both in the form of supporting instruments, information, appreciation, and emotions, This is important considering the current conditions / atmosphere affect the selection of majors.
\end{abstract}

Keywords: Parental Support, Satisfaction, Department Selection

Dipublikasikan Oleh :

UPT Publikasi dan Pengelolaan Jurnal

Universitas Islam Kalimantan Muhammad Arsyad Al-Banjari Banjarmasin 


\section{PENDAHULUAN}

Lembaga pendidikan baik yang bersifat umum maupun kejuruan adalah salah satu lembaga yang bertujuan untuk membentuk dan mengembangkan, bakat, kepribadian, sikap mental, kreatifitas, penalaran, pengetahuan, serta kompetensi seseorang. Pendidikan mempunyai fungsi dan peran yang sangat strategis dalam meningkatkan kerakter sumber daya manusia menjadi lebih baik. Salah satu komponen mutu sumber daya manusia di masa yang akan datang yaitu sumber daya manusia yang mampu mempunyai keahlian. Sekolah Menengah Kejuruan atau sering disebut SMK ialah salah satu sistem pendidikan menengah yang menciptakan calon tenaga kerja yang mempunyai keahlian sebanding dengan kesesuaian pasar di masing-masing bidangnya.

Pendidikan Menengah Kejuruan (SMK) yaitu pendidikan formal yang melangsungkan pendidikan kejuruan pada jenjang pendidikan menengah sebagai lanjutan dari sekolah menengah pertama atau bentuk lain yang sederajat maupun lanjutan dari hasil belajar yang diakui sama/setara SMP/MTs yang mempersiapkan seseorang untuk memiliki keahlian tertentu. Pendidikan Menengah Kejuruan memprioritaskan penyiapan siswa untuk memasuki lapangan kerja serta dapat mengembangkan sikap profesional sehingga diharapkan siswa lulusan SMK nantinya dapat diterima bekerja di dunia usaha ataupun dunia industri dengan mengandalkan skill yang sudah dipelajari dibangku sekolah. sebanding dengan bentuknya, Sekolah Menengah Kejuruan mengadakan program-program pendidikan yang disesuaikan dengan klasifikasi yang dibutuhkan di lapangan kerja.

Siswa atau siswi yang ingin menempuh pendidikan di Sekolah Menengah Kejuruan (SMK) tentunya harus mempertimbangkan jurusan yang dipilih. Pemilihan jurusan oleh siswa yang ingin menempuh pendidikan di SMK sangat penting. Akan tetapi, faktanya terdapat berbagai masalah siswa dalam memilih jurusan. Menurut Daryanto \& Munawaroh dalam Itryah. (2013) bahwa problem yang sewaktu-waktu terjadi dan dihadapi anak sekolah saat akan memilih jurusan adalah remaja sebagai pelajar yang terkadang masih terpengaruh oleh bujukan keluarga saat memilih jurusan atau kurang keyakinan dalam diri pelajar dengan pilihan jurusan disebabkan minimnya informasi yang diterima. Akibat kesalahan dalam pemilihan jurusan dapat membuat anak merasa tertekan, tidak semangat dalam belajar, bermasalah akademis kesulitan memahami materi pembelajaran, kurang percaya diri dan berdampak pada rendahnya nilai prestasi. Menurut Itryah, I. (2013) siswa tidak mampu menetapkan dan memutuskan pemilihan jurusan karena banyak pertimbangan karena banyak desakan atau tekanan. Menjadi ragu-ragu, bimbang, bahkan tekanan itu diperoleh oleh orang tua, teman, dan guru juga yang menginginkan jurusan.

Pemilihan jurusan dapat dipengaruhi berbagai faktor, baik faktor lingkungan sekolah maupun faktor lingkungan keluarga. Kedua orang tua memberikan pengaruh sangat besar terhadap penentuan pemilihan jurusan anak. Penelitian terdahulu yang dilakukan Hapsari, P. E. Pada tahun 2011 yang berjudul Pengaruh Kelompok Teman Sebaya dan Bimbingan Orang Tua terhadap Pemilihan Penjurusan pada Siswa SMK (Studi Kasus pada Siswa Kelas X SMK Negeri 2 Slawi). Hasil penelitian ini menunjukan bahwa bimbingan orang tua berpengaruh terhadap pemilihan penjurusan pada siswa SMK Negeri 2 Slawi, yang ditunjukan oleh hasil uji $\mathrm{t}$ dimana $\mathrm{t}$ hitung $(2,887)>\mathrm{t}$ tabel $(2,014)$ sehingga Ha diterima, dengan nilai koefisien determinasi sebesar $39,5 \%$ ini berarti orang tua berperan di dalam pendidikan anaknya dengan harapan selepas menyelesaikan pendidikan di SMK anak mereka akan bekerja searah dengan jurusan yang memiliki prospek gemilang dalam lapangan kerja.

Dukungan orang tua merupakan pemberian yang disediakan orang tua sebagaimana orang yang bertanggung jawab terhadap pendidikan ataupun keperluan hidup lainnya, bantuan yanag dapat diberikan berupa materi, penghargaan, maupun menyediakan informasi yang berguna untuk anak. Dalam memutuskan pemilihan jurusan, orangtua juga memiliki peran untuk campur tangan dalam proses pengambilan keputusan jurusan pendidikan pada anaknya. Posisi orangtua yang strategis dalam keluarga dan adanya kontrol yang mengharuskan orang tua ikut serta dalam hal tersebut.

Dukungan orang tua diharapkan menjadi penguat bagi siswa dalam memutusakan pemilihan jurusan, sehingga siswa mampu menetapkan pilihannya dan pemilihan program kejuruan dengan matang. Orang tua adalah komponen keluarga yang terdiri dari bapak dan ibu, dan merupakan hasil dari sebuah ikatan perkawinan yang sah yang dapat membentuk sebuah keluarga, orang tua atau keluarga inti adalah tempat pertama bagi seorang individu dalam mengolah motivasi hidupnya. Lingkungan keluarga merupakan lingkungan yang utama bagi seseorang manusia belajar bersosialisasi untuk pembentukan individu yang berkarakter. Menurut

Dipublikasikan Oleh :

UPT Publikasi dan Pengelolaan Jurnal

Universitas Islam Kalimantan Muhammad Arsyad Al-Banjari Banjarmasin 
W.A Gerunga, dalam, At-Thariq, M. R., \& Sugandi, R. M. (2018). "Keluarga merupakan kelompok sosial yang pertama dalam kehidupan manusia, tempat ia belajar dan menyatakan diri sebagai manusia sosial di dalam hubungan interaksi dengan kelompoknya".

Siswa yang sudah menentukan pemilihan jurusan dan setelahnya diterima di jurusan akan menerima segala hal baru, baik berupa akademik ataupun non akademik, dan mulai memasuki lingkungan baru merupakan hal yang tak kalah penting, seiring berjalannya waktu, penerimaan informasi dan hal-hal yang baru dalam jurusan akan membentuk perasan siswa terhadap jurusan. Perasaan yang ditimbulkan baik berupa perasaann yang satisfied dan not satisfied (puas dan tidak puas). Lounsbury dan Gibson (dalam, Nugrahini, A. K. 2018) menyatakan bahwa kepuasan terhadap jurusan berkaitan dengan tingkat kesejahteraan serta kepuasan hidup individu tersebut diwaktu yang akan datang. Dengan demikian, kepuasan dalam menjalani jurusan yang sedang dijalani merupakan hal yang penting bagi siswa. Kepuasan merupakan pandangan atau perasaan emosional yang timbul dari diri sesorang, perasaan tersebut berupa perasaan senang atau kecewa yang muncul setelah menilai hasil yang dipikirkan terhadap hasil yang diharapkan oleh siswa.

Berdasarkan hasil observasi dan wawancara langsung ke beberapa siswa kelas XI bahwa terdapat 8 siswa yang mengatakan mengambil keputusan pemilihan jurusan di SMK Negeri 1 Simpang Empat dikarenakan dukungan orang tua yang berpendapat bahwa jurusan yang dipilih tersebut mempunyai prospek kerja yang bagus. 6 dari 8 siswa tersebut mengatakan merasa puas dengan jurusan yang telah dipilih dan 2 siswa mengatakan tidak puas dengan pilihan tersebut.

Berdasarkan deskripsi di atas penulis tertarik mengungkapkan masalah ini dengan alasan dukungan orang tua merupakan hal yang dapat mempengaruhi kepuasan dalam pemilihan jurusan siswa SMK. Dalam penelitian ini peneliti ingin mengetahui Korelasi Dukungan Orang Tua Terhadap Kepuasan Pemilihan Jurusan Siswa Kelas X Di SMK Negeri 1 Simpang Empat Kabupaten Banjar.

\section{METODE}

Desain penelitian ini adalah penelitian korelasi, suatu penelitian yang melibatkan tindakan pengumpulan data, guna menentukan apakah ada hubungan dan tingkat hubungan antara dua variabel atau lebih. Adanya hubungan dan tingkat variabel ini penting, karena dengan mengetahui tingkat hubungan yang ada, peneliti akan dapat mengembangkannya sesuai dengan tujuan penelitian. Penelitian korelasi, seperti yang dikatakan Gay, merupakan salah satu bagian penelitian ex-post facto karena biasanya peneliti tidak memanipulasi keadaan variabel yang ada dan langsung mencari keberadaan hubungan dan tingkat hubungan variabel yang direfleksikan dalam koefisien korelasi (Sukardi, 2013). Populasi penelitian adalah siswa kelas XI SMKN 1 Simpang Empat yang berjumlam 213 orang, sampel berjumlah 139 orang yang dipilih dengan teknik simple random samping mengenai teknik pengumpulan data yang dibutuhkan dalam penelitian diambil dengan mengggunakan angket (kuesioner) berbentuk checklist. Dukungan orang tua yang dimaksud pada penelitian ini adalah sikap dan perilaku orang tua yang berupa dukungan insruemntal, emosional, penghargaan dan pemeberian informasi yang menunjang kepuasan pemilihan jurusan anaknya. Data dianalisis menggunakan uji normalitas, uji linearitas, dan analisis korelasi dibantu dengan menggunakan aplikasi SPSS versi 22.

Hipoteisi dalam penelitian ini yaitu :

a. Hipotesis Nol (H0) = yakni tidak ada adanya hubungan dukungan orang tua terhadap kepuasan pemilihan jurusan siswa kelas $\mathrm{X}$ di SMK Negeri 1 Simpang Empat.

b. Hipotesis Penelitian $(\mathrm{Ha})=$ yakni adanya hubungan dukungan orang tua terhadap kepuasan pemilihan jurusan siswa kelas $\mathrm{X}$ di SMK Negeri 1 Simpang Empat.

\section{HASIL DAN PEMBAHASAN}

Sebelum melakukan uji prasyarat dan analisis yang dilakukan terlebih dahulu peneliti melakukan pengkategorian data dengan mencantumkan nilai minimal dan nilai maksimal item pertnyataan yang talah di sebarkan kepada responden. Dari jumlah sampel 139 didapatkan hasi pengkatergorian seperti pada tabel 1 dan tabel 2.

\section{Tingkat Kategori Dukungan Orang Tua}

Data dukungan orang tua yang berjumlah 139 orang yang disajikan pada tabel dapat dipahami bahwa tidak ada siswa yang memiliki skor pada kelompok 56 ke bawah yang tergolong pada klasifikasi rendah $0 \%$, sebagian kecil siswa memiliki skor pada kelompok 56-84 ke atas yang tergolong pada klasifikasi sedang yang berjumlan 32 siswa $23 \%$, dan beberapa siswa memiliki skor 84 pada kelompok yang tergolong pada klasifikasi tinggi yang berjumlan 107 siswa 77\%. Hal ini menunjukkan

Dipublikasikan Oleh : 


\section{Melly ${ }^{1}$, Sultani $^{2}$, Aminah $^{3}$ \\ Jurnal Mahasiswa BK An-Nur : Berbeda, Bermakna, Mulia}

Volume 7 Nomor 2 Tahun 2021

Tersedia Online: https://ojs.uniska-bjm.ac.id/index.php/AN-NUR

p-ISSN. 2460-9722 | e-ISSN. 2622-8297

dukungan orangtua di SMK Negeri 1 Simpang Empat tergolong pada klasifikasi tinggi.

\section{Tingkat Kategori Kepuasan pemilihan jurusan}

Data kepuasan pemilihan jurusan yang berjumlah 139 orang yang disajikan pada tabel 2 diketahui bahwa dapat dipahami bahwa tidak ada siswa yang memiliki skor pada kelompok $66.5 \mathrm{ke}$ bawah yang tergolong pada klasifikasi rendah jumlah

Tabel 1. Distribusi Frekuensi Dan Presentasi Dukungan Orang Tua

\begin{tabular}{llll}
\hline $\begin{array}{l}\text { Interval } \\
\text { skor }\end{array}$ & Kategori & Frekuensi & $\begin{array}{l}\text { Persentasi } \\
(\%)\end{array}$ \\
\hline$>84$ & Tinggi & 107 & $77 \%$ \\
$56-84$ & Sedang & 32 & $23 \%$ \\
$<56$ & Rendah & 0 & $0 \%$ \\
\hline & Tolat & 139 & 100 \\
\hline
\end{tabular}

Table 2 Distribusi Frekuensi Dan Presentasi kepuasan Pemilihan Jurusan

\begin{tabular}{llll}
\hline $\begin{array}{l}\text { Interval } \\
\text { skor }\end{array}$ & Kategori & Frekuensi & $\begin{array}{l}\text { Persentasi } \\
(\%)\end{array}$ \\
\hline$<101,5$ & Tinggi & 107 & $77 \%$ \\
$65.5-$ & Sedang & 32 & $23 \%$ \\
101.5 & & & \\
$>65.5$ & Rendah & 0 & $0 \%$ \\
\hline & & 139 & 100 \\
\hline
\end{tabular}

Berdasarkan hasil penelitian yang dilaksanakan di SMKN 1 Simpang Empat Kabupaten Banjar, menggunakan angket sebagai alat pengukuran data dengan sampel sebanyak 139 siswa. Penelitian dengan menggunakan kuesioner ini, telah memberikan jawaban yang cukup jelas terhadap rumusan masalah yang telah diajukan pada bab sebelumnya serta telah membuktikan hipotesis yang digunakan sebagai jawaban sementara sebelum penelitian.

Berdasarkan hasil penjabaran sebelumnya, diketahui bahwa sebanyak 107 orang dengan prosentase $77 \%$ yang berada pada kategori tinggi menunjukkan bahwa siswa-siswi SMKN 1 Simpang Empat Kabupaten Banjar melakukan dukungan orang tua mereka. Siswa-siswi yang menunjukkan prosentase tinggi terhadap dukungan orang tua tersebut mengindikasikan bahwa menurut mereka, mereka merasa mendapatkan dukungan dari orang tua mereka. Hal ini ditunjukkan dengan adanya perhatian yang diberikan oleh orang tua kepada siswa
0 siswa $0 \%$, sebagian kecil siswa memiliki skor pada kelompok 66.5 -101.5 ke atas yang tergolong pada klasifikasi sedang sebanyak 32 siswa $23 \%$ dan sebagian besar siswa memiliki skor pada kelompok 101.5 yang tergolong pada klasifikasi tinggi sebanyak 107 siswa 77\% . Hal ini menunjukkan minat belajar di SMK Negeri 1 Simpang Empat tergolong pada klasifikasi tinggi.

Orang tua adalah orang yang pertama dan utama yang bertanggungjawab terhadap kelangsungan hidup dan pendidikan anaknya menurut Hasbullah (Baiti, A. A., \& Munadi, S. 2014). Oleh karena itu para orang tua hendaknya memperhatikan perkembangan anak agar dapat berkembang sesuai usianya. Didalam keluarga tempat dimana orang tua mendidik anaknya untuk membantu pertumbuhan dan perkembangan anak untuk mengikuti dan melanjutkan pendidikan formal.

Didukung dengan penelitian Husna, R. K., \& Taufik, N. Pada tahun 2017 yang berjudul Hubungan Dukungan Sosial Orangtua dengan Minat Pilihan Karir Siswa (Doctoral dissertation, Universitas Negeri Padang). Hasil penelitian menunjukkan bahwa Dukungan sosial orangtua secara keseluruhan pada katgori sangat baik $8,64 \%$ Temuan ini menunjukkan bahwa secara keseluruhan dukungan sosial orangtua pada kategori baik. Maka dapat disimpulkan ada hubungan yang positif signifikan antara dukungan sosial orangtua dengan minat pilihan karir siswa.

Sedangkan siswa di SMKN 1 Simpang Empat Kabupaten Banjar, yang mempunyai tingkat dukungan orang tua pada kategori rendah sebesar $0 \%$, yaitu tidak ada siswa dari 139 sampel penelitian yang menyatakan dukungan orang tuanya rendah. Hal tersebut menunjukkan bahwa siswa memiliki pengaruh positif, maka dapat disimpulkan bahwa dukungan orang tua terhadap kepuasan pemilihan jurusan memiliki hubungan yang berbentuk positif dibuktikan dengan hasil uji korelasional.

Sarafino (dalam, Laden, M. 2014) membagi dukungan orang tua ke dalam 4 bentuk, yaitu: a) Dukungan emosional. Aspek ini meliputi ungkapan empati, kepedulian dan perhatian terhadap orang yang bersangkutan.b) Dukungan penghargaan. Aspek ini terjadi lewat ungkapan penghargaan positif untuk individu bersangkutan, dorongan maju atau persetujuan dengan gagasan atau perasaan individu dan pertimbangan positif individu dengan orang-orang lain. c) Dukungan informatif. Aspek ini mencakup memberi nasihat, petunjukpetunjuk, saran-saran, informasi, dan umpan balik. d)

Dipublikasikan Oleh :

UPT Publikasi dan Pengelolaan Jurnal

Universitas Islam Kalimantan Muhammad Arsyad Al-Banjari Banjarmasin 


\section{Nama Penulis \\ Jurnal Mahasiswa BK An-Nur : Berbeda, Bermakna, Mulia \\ Volume....Nomor.....,Tahun \\ Tersedia Online: https://ojs.uniska-bjm.ac.id/index.php/AN-NUR \\ p-ISSN. 2460-9722 \\ e-ISSN. 2622-8297}

Dikungan instrumental. Dukungan instrumental adalah bentuk dukungan langsung yang diwujudkan dalam bentuk bantuan material atau jasa yang dapat digunakan untuk memecahkan masalah-masalah secara praktis.

Tingkat tertinggi kepuasan berada pada kategori tinggi. Dari hasil analisa menunjukkan $77 \%$ atau 107 siswa dari 139 responden penelitian ada pada tingkat tinggi. Artinya siswa bisa dikatakan puas terhadap kepuasan pemilihan jurusan. Hal tersebut dapat terlihat ketika mereka dapat mengahargai diri mereka sendiri, Kepuasan siswa pada kategori tinggi ini, bisa dilihat dari hasil angket yang menyatakan bahwa siswa merasa puas ketika mereka mampu dalam beradaptasi dilingkungan kejuruan, mampu mengubah orientasi mereka sendiri untuk memenuhi persyaratan dari perubahan peran sebagai siswa serta dapat mengerjakan tugas dan tanggung jawab.

Sedangkan kepuasan pada siswa SMKN 1 Simpang Empat Kabupaten Banjar, berada pada kategori sedang sebanyak 32 dari 139 sampel penelitian. Hasil ini menunjukkan ada beberapa siswa yang merasa dirinya bisa dikatakan puas tetapi juga tidak terlalu puas.

Tingkat dominasi berada pada kategori rendah, yaitu menunjukkan $0 \%$ atau sebanyak 0 siswa dari 139 sampel penelitian, yang artinya siswa mempunyai tingkat kepuasan yang rendah. Hal ini memperlihatkan bahwa siswa merasa kebutuhannya terpenuhi sehingga timbul perasaan puas yang dirasakan oleh mereka, karena adanya kemungkinan terpenuhinya aspek-aspek yang ada dalam kepuasan pada diri siswa tersebut. Siswa dapat membiasakan untuk mengaktualisasikan diri mereka terutama mengenai kemampuan mereka dalam bidang akademik ataupun non akademik, ataupun terkait tentang jurusan yang ia pilih.

Suryani, A. I (2020) berpendapat bahwa pemilihan jurusan pada dasar pertimbangan dalam memilih jurusan dapat ditinjau dari: a) Kemampuan dasar umum (kecerdasan) b) Bakat, minat dan kecenderungan pribadi c) Hasil Belajar d) Ketersediaan fasilitas sekolah e) Dorongan moral dan finansial dari orangtua. Prospektif atau tidaknya suatu jurusan, bukan ditentukan oleh baik buruknya jurusan yang dipilih, namun dari niat, minat, dan kemampuan yang dimiliki oleh siswa. Sehingga siswa dapat mengembangkan kompetensinya secara optimal dengan adanya jurusan-jurusan tersebut, seandainya siswa dapat mengoptimalkan kemampuannya sesuai jurusan yang diminatinya, kemungkinan siswa tersebut juga akan mempunyai masa depan yang terarah dengan baik dan kemungkinan salah pilih jurusan pun tidak ada.

Analisa hipotesa telah terjawab bahwa ada pengaruh dukungan orang tua terhadap kepuasan memilih jurusan pada siswa SMKN 1 Simpang Empat. Hal ini dibuktikan dengan hasil analisis yang menggunakan bantuan SPSS ver 22, yaitu diperoleh koefisien korelasi sebesar 0,660 (positif) dan taraf signisikansi sebesar 0,000. Hal ini menunjukkan bahwa terdapat pengaruh yang signifikan. Semakin tinggi dukungan orangtua maka akan semakin tinggi pula kepuasan memilih jurusan yang mereka rasakan.

Pada tingkat kepuasan, untuk mengetahui kepuasan seseorang sudah terpenuhi atau tidak dapat kita lihat dari penilaian perilaku siswa terhadap vokasional, penilaian nilai-nilai diri, penilaian kekampuan dan penilaian kebutuhan siswa tersebut, tetapi terdapat faktor-faktor lain yang dapat mempengaruhi kepuasan yang tidak terungkap dalam penelitian ini. Terpenuhinya kebutuhan- kebutuhan tersebut secara memadai akan menimbulkan keseimabangan dan keutuhan pribadi. Remaja yang kebutuhannya terpenuhi secara memadai akan memperoleh suatu kepuasan hidup. Para remaja akan merasa gembira, harmonis, produktif dan merasa puas manakala kebutuhannya terpenuhi.

Hasil perhitungan uji korelasi diketahui bahwa Nilai Correlation Coefficient positif yaitu 0,660. Hal ini menyatakan bahwa hubungan kedua variabel searah yaitu semakin ditingkatkan dukungan keluarga maka semakin tinggi pula kepuasan pemilihan jurusan.

Hubungan antara dukungan orangtua dengan pengambilan kepuasan pemilihan jurusan sependapat dengan apa yang dinyatakan Sarafino (Baiti, A. A., \& Munadi, S. 2014). Dukungan seseorang yang berada didalam lingkungannya dalam keadaan tertentu dapat mempengaruhi keadaan tersebut baik hasilnya maupun hanya kondisi dan akan memberikan keuntungan emosional bagi anak yang diberi dukungan.

Berdasarkan uraian di atas dapat disimpulkan bahwa dukungan orang tua berhubungan dengan kepuasan pemilihan jurusan pada siswa kelas XI SMKN 1 Simpang Empat. Hal ini dapat terjadi jika orangtua dapat memenuhi dan mendukung kebutuhan anak dalam bentuk apapun untuk menunjang keperluan dalam hal pendidian, dan anak merasa memiliki kesesuaian antara minat dan kemampuan

Dipublikasikan Oleh : 
dalam mengambil suatu keputusan pemilihan jurusan, yang nantinya akan berpengaruh pada hasil kepuasan atau ketidakpuasan yang dirasakan siswa, perasaan senang atau kecewa yang muncul setelah membandingkan antara persepsi/kesannya terhadap jurusan yang sudah ia pilih, selain itu terdapat pengaruh lainnya seperti, lingkungan teman sebaya, minat bakat terkait program jurusan yang mempengaruhi dalam hal ini faktor lain selain dukungan orangtua, sehingga dukugan orangtua.

Hipotesis yang ditemukan dalam penelitian ini adalah : Ha $: \rho \neq 0$ terdapat hubungan yang positif dan signifikan antara dukungan orangtua terhadap kepuasan pemilihan jurusanpada siswa kelas XI SMKN 1 Simpang Empat. Semakin ditingkatkan dukungan keluarga maka semakin tinggi pula kepuasan pemilihan jurusan siswa.

\section{PENUTUP \\ Kesimpulan}

Berdasarkan hasil analisis data dan pembahasan yang dikemukakan maka dapat disimpulkan hipotesa telah dilakukan menyatakan bahwa ada pengaruh yang signifikan antara dukungan orang tua terhadap kepuasan memilih jurusan pada siswa SMKN 1 Simpang Empat. Hipotesis hasil penelitian yang didapat Ha : terdapat hubungan yang positif dan signifikan antara dukungan orang tua terhadap kepuasan pemilihan jurusan pada siswa kelas XI SMKN 1 Simpang Empat. Semakin ditingkatkan dukungan keluarga maka semakin tinggi pula kepuasan pemilihan jurusan siswa.

\section{Saran}

Guru dan konselor dapat memberikan pengarahan atau sosialisasi mengenai pentingnya program jurusan yang ada di sekolah, sehingga sisiwa tidak kekurangan informasi mengenai jurusan yang akan dipilih. Selain agar siswa memiliki informasi mengenai jurusan sisiwa juga dapat mengetahui kemampuan yang ada dalam dirinya, sehingga siswa dapat memilih jurusan sesuai dengan kemampuannya yang nantinya akan berakibat kepada kepuasan siswa tersebut.

Bagi orang tua agar orang tua saling memberikan dukungan penuh pada anak, baik berupa dukungan instument, informasi, penghargaan, dan emosi, hal ini penting mengingat kondisi/suasana yang sedang berlangsung mempengaruhi pemilihan jurusan.
Bagi peneliti selanjutnya dapat melengkapi hasil penelitian dari hasil penelitian ini dari sisi penyempurnaan item. Mendalami literatur dengan lebih mendalam mengenai faktor atau bentuk hubungan terhadap dukungan orangtua terhadap kepuasan pemilihan jurusan.

\section{REFERENSI}

Baiti, A. A., \& Munadi, S. (2014). Pengaruh pengalaman praktik, prestasi belajar dasar kejuruan dan dukungan orang tua terhadap kesiapan kerja siswa SMK. Jurnal Pendidikan Vokasi, 4(2).

Hapsari, P. E. (2011). Pengaruh Kelompok Teman Sebaya dan Bimbingan Orang Tua terhadap Pemilihan Penjurusan pada Siswa SMK (Studi Kasus pada Siswa Kelas X SMK Negeri 2 Slawi) (Doctoral dissertation, Universitas Negeri Semarang).

Laden, M. (2014). Peranan Dukungan Orang Tua Dengan Keputusan Memilih Jurusan di Perguruan Tinggi Pada Siswa Kelas Xii SMA Katolik WR Soepratman Samarinda. Psikoborneo, 2(2).

Sukardi. 2013. Metodologi Penelitian Pendidikan. Jakarta: PT Bumi Aksara.

Suryani, A. I (2020). Peran Guru Bimbingan Konseling dalam Pemilihan Jurusan di Sekolah Menengah Atas Negeri 2 Silak Gulu Kecamatan Siak Hulu Kabupaten Kampar Provensi Riau (Doctoral Dissertation, Universitas Islam Negeri Sultan Syarif Kasim Riau).

Nugrahini, A. K. (2018). Faktor-Faktor Yang Mempengaruhi Pemilihan Jurusan Dan Kepuasan Dalam Menjalani Jurusan Diperguruan Tinggi, (Doctoral Dissertation, Universitas Dharma Yogyakarta).

Itryah, I. (2013). Interaksi Keluarga Dan Peran Orang Tua Terhadap Keputusan Pemilihan Jurusan Pada Siswa SMA Di Palembang.

Husna, R. K., \& Taufik, N. (2017). Hubungan Dukungan Sosial Orangtua dengan Minat Pilihan Karir Siswa (Doctoral dissertation, Universitas Negeri Padang). 